IZA DP No. 5369

Why Children of College Graduates Outperform their Schoolmates: A Study of Cousins and Adoptees

Torbjørn Hægeland

Lars Johannessen Kirkebøen

Oddbjørn Raaum

Kjell G. Salvanes

December 2010 


\title{
Why Children of College Graduates Outperform their Schoolmates: A Study of Cousins and Adoptees
}

\author{
Torbjørn Hægeland
}

Statistics Norway

\section{Lars Johannessen Kirkebøen}

Statistics Norway

Oddbjørn Raaum

Frisch Centre

\author{
Kjell G. Salvanes \\ Norwegian School of Economics, \\ Statistics Norway, CEE and IZA
}

\section{Discussion Paper No. 5369 \\ December 2010}

\author{
IZA \\ P.O. Box 7240 \\ 53072 Bonn \\ Germany \\ Phone: +49-228-3894-0 \\ Fax: +49-228-3894-180 \\ E-mail: iza@iza.org
}

\begin{abstract}
Any opinions expressed here are those of the author(s) and not those of IZA. Research published in this series may include views on policy, but the institute itself takes no institutional policy positions.

The Institute for the Study of Labor (IZA) in Bonn is a local and virtual international research center and a place of communication between science, politics and business. IZA is an independent nonprofit organization supported by Deutsche Post Foundation. The center is associated with the University of Bonn and offers a stimulating research environment through its international network, workshops and conferences, data service, project support, research visits and doctoral program. IZA engages in (i) original and internationally competitive research in all fields of labor economics, (ii) development of policy concepts, and (iii) dissemination of research results and concepts to the interested public.
\end{abstract}

IZA Discussion Papers often represent preliminary work and are circulated to encourage discussion. Citation of such a paper should account for its provisional character. A revised version may be available directly from the author. 
IZA Discussion Paper No. 5369

December 2010

\section{ABSTRACT}

\section{Why Children of College Graduates Outperform their Schoolmates: A Study of Cousins and Adoptees}

Massive cross-sectional evidence exists indicating that children of more educated parents outperform their schoolmates. However, evidence for causal interpretation of this association is weak. We examine a causal relationship using two approaches for identification within the same data: cousins with twin parents and adopted children. We find no effect of mothers' education on children's school performance using the children-of-twins approach. However, for adopted children, mother's education has a small positive effect. Tracking the work experience of parents during offspring childhood, we find no support that this effect can be explained by a higher labor force participation among more educated mothers.

JEL Classification: $\quad$ I121

Keywords: intergenerational mobility, education, twin parents, adoptees

Corresponding author:

Kjell G. Salvanes

Department of Economics

Norwegian School of Economics

and Business Administration

Helleveien 30

N-5035 Bergen-Sandviken

Norway

E-mail: kjell.salvanes@nhh.no

\footnotetext{
* This paper is part of the project "Student achievement: disentangling the effects of social background and schools" (158102-S20) supported by the program "Competence, Education and Learning" within the Norwegian Research Council. Comments from Sandra Black, Magne Mogstad, Erik Plug, Arvid Raknerud, participants at the workshop "The Effect of Parental Workforce Participation on Children" at the University of Stavanger, and seminar participants at Tinbergen Institute, Frisch Centre and Norwegian School of Economics, are gratefully acknowledged.
} 


\section{Introduction}

There is massive cross-sectional evidence that children of more educated parents outperform their schoolmates in terms of test and exam results, grade repetition and educational attainment. ${ }^{1}$ Many mechanisms could explain such correlations. Education may influence parents' fostering skills in terms of investment in children and preferences for education. The correlation may also reflect common pre-birth factors such as genetic influence on cognitive skills and child-rearing capabilities. Understanding the mechanisms that drive the intergenerational transmission in education is crucial in order to design educational policies. For instance, the scope for educational reforms such as increasing the length of compulsory schooling will be much larger if there is a causal link between the education level of parents and the schooling achievement of children.

When trying to disentangle the causal effect of parental schooling from the effects of pre-birth factors, several recent papers, using different identification strategies like children of twins or school reforms instruments, report weak causal effects of parental education on their children's educational performance (Behrman and Rosenzweig, 2002; Black, Devereux, and Salvanes, 2005). In particular, a weak causal effect of mother's education on her children is surprising and goes against conventional wisdom. On the other hand, studies using adoptees (and other time periods and data sources than the above studies) find stronger effects of mother's schooling on children's schooling (Plug, 2004; Sacerdote, 2007). A deeper understanding of these different and partly puzzling results will be vital in directing public policy in terms of education.

\footnotetext{
${ }^{1}$ See Behrman (1997) for an overview of international evidence of the importance of mothers' education for children's education, and Haveman and Wolfe (1995) for a general overview of the literature on family background and children's performance.
} 
In this paper, we make two contributions to the literature. First, within the same population and data set, we use two alternative empirical strategies to identify the causal effect of parents' education on their children's exam scores. Second, by tracking the work experience of parents during child rearing years, we investigate why mother's education is found to have only a weak effect on children's outcomes. A contemporary study by Holmlund, Lindahl and Plug (2008) on Sweden is in the same spirit as ours, as they use the same identification strategies. However, they do not investigate the role of parental employment during offspring childhood.

In order to understand the importance of identification strategies for the difference in results, as opposed to country and data period differences, we compare two such strategies: children of twins and adoptees. We first study the outcomes of children of twins and non-twin siblings, who share more of both environment and genes than two pupils with the same observed family background. Then we turn to adopted children randomly allocated to Norwegian families, who only share their parents' environments. Because most previous studies have only used one of these approaches for each data set (and country), it is important to check whether the two strategies provide the same results or whether the main results depend on the data set used. The impact of education may have changed over time, and this paper distinguishes itself by using more recent cohorts (children born 1986-1991) than previous studies; e.g., Behrman and Rosenzweig (2002), who use parents born from the mid-1930s to the mid-1950s.

Then we ask the question why more education per se does not seem to improve the quality of investments in children's education made by parents. From the literature, we know that early parental investment in terms of both time and resources is important for cognitive development and human capital accumulation, particularly 
during preschool years and even within the first year after birth (Carneiro and Heckman, 2003; Heckman and Masterov, 2007). Educated mothers who work more generate economic resources that provide a more favourable environment for the family. However, keeping family income constant, there could be a negative effect from less time spent with their children among highly educated mothers with long working hours. The results from the empirical literature studying the effect of maternal employment during early child rearing on children's short term and long term outcomes are ambiguous (Waldfogel, 2006; Baum, 2003; Berger, Hill, and Waldfogel, 2005; Carneiro, Løken and Salvanes, 2009; Dustmann and Schønberg, 2008). We test the effect of parental work on children's school performance by carefully tracking work experience during offspring childhood and examining the impact of mothers' working patterns on their children’s outcomes.

Our data set consists of the complete cohorts of 16-year-olds completing lower secondary school from 2002 to 2007 in Norway. Our outcome measures are final marks in lower secondary school. Using administrative registers with common person identifiers, we can link all children to their parents and to their grandparents. This allows us to identify siblings, twins and cousins. We also have information on children that were adopted from abroad, including country of birth and date of adoption. Other registers provide information on level of education and a long timeseries of parental labour earnings and labour force participation.

We find that the two alternative identification strategies-applied on the same data in terms of cohorts and variables_-give different results. We show that there is a strong cross-sectional correlation between both parents' education and the educational outcome of their children, even when controlling for a rich set of family background variables including variables reflecting assortative matching. Comparing cousins, the 
effect of mother's education on children's educational outcome disappears when the parents are twins. The point estimate of the effect of father's education is reduced less when the fathers are twins, but it is also insignificant. The results are robust to several checks including testing for non-linear effects as well as instrumenting for possible measurement error in education. When we restrict the sample of adopted children to those adopted at a young age (as we should do in adoption studies), we do find a statistically significant, but small, effect of mother's education but no significant effect of father's education. All in all, we obtain very similar results to recent studies such as Behrman and Rosenzweig (2002), Plug (2004) and Black, Devereux and Salvanes (2005). Carefully tracking the work experience of parents during offspring childhood, we find no indication that labour force participation among highly educated mothers has detrimental effects on their children's school performance.

The paper unfolds as follows. In the next section, we provide an overview of the previous literature. Section 3 contains the econometric specifications, and in Section 4, we describe our data and adoption and education institutions. Section 5 presents the results, while Section 6 reports robustness checks. In Section 7 we address whether working patterns among mothers can explain the zero causal effect of mother's education. Section 8 concludes.

\section{Literature}

To identify the intergenerational transmission of human capital, four main approaches have been taken in recent studies: children of identical twins, adoptees, instrumental variables, and lastly a smaller literature specifying structural models. Unlike typical twins studies focusing on variations in outcomes among genetically identical individuals, Behrman and Rosenzweig (2002) follow the children of twins (COT) 
tradition in behavioural genetics and compare outcomes among cousins with identical twin parents. ${ }^{2}$ The idea is to "difference out" the correlation between parental education and genetic endowments passed over to the next generation by nature. Using the Minnesota Twin Registry data, Behrman and Rosenzweig (2002) find strong positive correlations between mother's education and child's education. However, the same relationship is negative and almost significant when they compare cousins whose mothers are monozygotic twins. Using the same approach for fathers yields coefficients for father's education that are about the same size as the OLS estimates. ${ }^{3}$ Note that both parents' education are included in their specification, as is standard in the recent literature on this topic, which implies that assortative matching is controlled for. Another paper using this identification strategy is Bingley, Christensen and Myrup Jensen (2009), who use identical twins from the Danish twins registry and several measures such as GPA, birth weight and years of education. Their results show no effect of mother's education on GPA in the ninth grade or on years of completed education (the latter effect is positive for parental cohorts born after 1945). Father's education is shown to have a significantly negative impact on children's GPA, while it has a positive effect on years of education (reversed for parental cohorts born after 1945; there is no effect of father's education on children's education).

The second strategy is to study adopted children to separate out the genetic component of intergenerational correlations. The idea is that any outcome resemblance between adopted children and their adoptive parents must be because of the environment and not genes. If children are randomly placed with adoptive parents,

\footnotetext{
${ }^{2}$ For a brief overview of the COT tradition in behavioural genetics, see D’Onofrio (2005).

${ }^{3}$ Antonovics and Goldberger (2003) question these results and suggest that the findings are highly sensitive to the coding of the data. They also suggest that it may be unrealistic to assume that twins differ in terms of education but not in terms of any other characteristic or experience that may influence the education of their offspring.
} 
the relationship between parental education and child education simply cannot reflect genetic factors. An early contribution by Dearden, Machin and Read (1997) use a small sample of adopted children from the UK and study years of schooling of fathers and adopted sons. They find a high intergenerational correlation, almost as high as in biological relationships, leading them to conclude that environmental factors are very important. More recently, Plug (2004) uses data on adopted children to investigate the causal relationship between parental education and child education. ${ }^{4}$ Plug (2004) finds a positive effect of father's education on child education but no significant effect of mother's education. Björklund, Lindahl and Plug (2006) use Swedish adoptees placed in the years from 1962 to 1966, and use information on biological parents to control for selective placement. They find a positive effect of adoptive fathers' education on their children's education, but again an insignificant effect of adoptive mothers when the education of the spouse and hence assortative matching is controlled for. However, they do find non-linear effects, because mothers' university education has a positive effect on children attending university. Sacerdote (2007), using adopted children from Korea to the US from 1964 to 1985 who were randomly assigned to adoptive parents, finds a strong effect of adoptive parents' education (and family size) on a number of child outcomes such as educational attainment, smoking and drinking behaviour.

The third approach is to use instrumental variables. Black, Devereux and Salvanes (2005) use a school reform that increased compulsory years of schooling. The reform took place over a 10 -year period in Norway, and was implemented in different years in different municipalities. In this way, the reform had the characteristics of a social experiment. The implementation year was used in addition

\footnotetext{
${ }^{4}$ Sacerdote (2002) also uses adoptees to distinguish the effect of family background on children's outcomes from genetic factors; however, the focus of his paper is the general impact of family socioeconomic status as opposed to the causal impact of parents' education.
} 
to municipality and cohort fixed effects to identify the causal effect of parental education on the children's education. They find a positive but very small causal effect only of mothers' education on their sons' educational attainment. Several papers use schooling law instruments to assess the effect of parental education on school outcomes for children. For instance, Oreopoulos, Page and Stevens (2006) take advantage of the sequential introduction of compulsory schooling legislation across US states and circumvent the problem of coincident time effects. They find that increasing the education of either parent has a significantly negative effect on the probability a child will repeat a grade. Carneiro, Meghir and Parey (2007) use different instruments for cost of schooling — such as the distance to college in the US - to assess the effect of parental education on their children's math and reading scores when they are eight years old and when they are 12-14 years old. They find a positive effect of both parents' education for their children at age eight, but no effect of mothers' education when children were 12-14 years. McNally and Maurin (2007) use the change in the qualification level required for admission to French universities in 1968 as a consequence of the student revolt in May, to identify the effect of parental education on their children. In line with Oreopoulos, Page and Stevens (2006), they find that an increase in parental education reduced grade repetition for the children. Page (2006) uses the G.I. Bill for World War II veterans to identify the effect of paternal education on their children's education. She finds that a one-year increase in paternal education reduces the chance of grade repetition by 2-3 percentage points.

In the fourth category, using structural estimation of the intergenerational transmission of education, Belzil and Hansen (2003) find that mothers' education has 
a negative effect on their children's education while fathers' education has a positive effect.

Holmlund, Lindahl and Plug (2008) use adoptees, parental twins, and a school reform instrument to compare results from different methods within the same data set for Sweden. In their main specifications, they find that the results differ to some degree across identification strategies. For twin mothers and fathers, there is no effect of mothers' education on child outcomes, but a small and significant effect of fathers' education. This result resembles the Behrman and Rosenzweig (2002) study. Using the adoption strategy, much smaller effects are found using foreign-born adopteesestimates in the range of $0.03-0.04$ for the effect of parents' years of schooling on children's years of schooling — than have been found in previous studies in particular in Sacerdote (2007). They also test the effect using a small sample of Korean adoptees as used in Sacerdote (2007), but the sample is too small to provide any significant result. For Swedish-born adoptees, the estimated intergenerational parameters are in the range of $0.03-0.11$ for both mothers and fathers and actually higher for mothers. Note that Björklund, Lindahl and Plug (2006) found that selection was important when using information on education for biological as well as adoptive parents for Swedish-born adopted children. Using the same type of educational reform that occurred in Norway for Sweden to instrument parental education, their results are also very much in line with Black, Devereux and Salvanes (2005); that is, no significant effect is found for fathers, and a significant but small effect is found for mothers. As in Black, Devereux and Salvanes (2005), they stress that identification using this reform comes from the lower part of the parental distribution, which is the part of the distribution aimed at and affected by the mandatory school reform. This implies that the IV results are to be interpreted as local average treatment effects. 
To summarize, there seems to be consensus that the causal intergenerational effect of education, i.e., controlling for inherited ability, is much lower than the correlation found from the OLS results. However, there are differences across methods, implying that slightly different parameters are estimated. The results using the COT strategy indicate a weak effect of fathers' education on children's educational attainment, but no effect of mothers' education. Clearly, if there are nonidentical (fraternal) twins in the sample, a potential positive correlation between inherited endowments and difference in education will give an upward bias to the intergenerational transmission of education. However, even using fraternal twins, Holmlund, Lindahl and Plug (2008) find very similar results to those in Behrman and Rosenzweig (2002). Larger effects are found when using adoptees as in Sacerdote (2007) and Plug (2004), and in particular a significant effect of fathers' education. Holmlund, Lindahl and Plug (2008) also find a significant effect of mothers' education, but only when Swedish-born adoptees are used. ${ }^{5}$ In papers using a mandatory school reform as an instrument for parental education, there is a positive effect of mothers' education on children's education although in this case the estimated effect is also much smaller than using OLS. It is also important to note that the variation identifying the effect comes from the lower end of the parental educational distribution.

\footnotetext{
${ }^{5}$ For domestic adoptions the random assignment assumption can be questioned.
} 


\section{Econometric specification and identification}

We start by presenting a reduced form intergenerational mobility model, similar to that of Behrman and Rosenzweig (2002) for educational achievement, where both parents (potentially) contribute to their children's outcome:

$$
Y^{c}=\delta_{1} S^{m}+\delta_{2} S^{f}+\Gamma_{1} h^{m}+\Gamma_{2} h^{f}+\Pi_{1} g^{m}+\Pi_{2} g^{f}+\lambda X+\varepsilon^{c},
$$

where $Y^{c}$ is the educational achievement of a child, and $S^{m}$ and $S^{f}$ are the education of the mother and the father, respectively. The $h$ 's are the unobserved heritable endowments of the parents, the $g$ 's represent their (unobserved) parental skills and child-rearing talents, and $X$ is a vector of observed family-specific variables such as age of parents at birth, grandparents' education (to capture, for instance, parts the inborn child-rearing skills of the parents), as well as child-specific demographic variables such as gender and year of birth.

The focus of this paper is on the $\delta_{i}$ parameters. They reflect how changes in parental schooling affect the child's educational achievement keeping other observed family characteristics $(X)$, heritable endowments $\left(h^{p}, p=m, f\right)$ and other unobserved parental chacteristics $\left(g^{p}, p=m, f\right)$ fixed. Potential channels of influence are numerous, as parental schooling may affect allocation of time and money as well as parenting skills and taste for education in both generations. In some specifications, we also include family earnings in the $X$ vector to focus on the effect of parental education that operates beyond the economic resources arising from more schooling. Conditioning on an endogenous variable is problematic but it turns out that our main results are not affected by inclusion of family earnings.

We cannot assume that, e.g., mother's schooling level is independent of her own heritable and child-rearing endowments, or, because of assortative matching, of 
the characteristics of the father. Generally, one would expect a positive correlation in all three dimensions, leading to an upward bias in $\widehat{\delta}_{1}$ when (1) is estimated directly using OLS. Thus, our exercise can be seen as an attempt to identify a tighter upper bound on the causal effect of parental education.

\subsection{Children of twins}

One way to eliminate or reduce the sources of the bias is, following Behrman and Rosenzweig (2002), to examine the differences between children with similar heritable endowments. For example, we consider the difference in (1) between cousins with twin mothers or fathers;

$$
\Delta Y^{c}=\delta_{1} \Delta S^{m}+\delta_{2} \Delta S^{f}+\Gamma_{1} \Delta h^{m}+\Gamma_{2} \Delta h^{f}+\Pi_{1} \Delta g^{m}+\Pi_{2} \Delta g^{f}+\lambda \Delta X+\Delta \varepsilon^{c} .
$$

We estimate this equation separately for twin fathers and twin mothers. In the case of monozygotic twin mothers, $\Delta h^{m}=0$. More generally, when studying the difference in educational outcomes between cousins with twin mothers, the effects of both genetic factors and unobserved child-rearing endowments are eliminated to the extent that these are shared and transmitted similarly by twin sisters. Because our data set does not contain information on zygosity, the subsample with twin mothers includes both fraternal and identical twins. Fraternal twins of the same sex are, like other siblings, 50 percent genetically related as opposed to monozygotic twins who are genetically identical. The fraternal twins in the sample are thus likely to contribute to a non-zero correlation between differences in $h$ and $S$. This may introduce an upward bias in the estimation of $\delta_{1}$.

Moreover, assortative matching may also cause correlation between the within-mothers schooling difference and the differential characteristics of the fathers. 
However, we expect that education, heritable and non-heritable endowments are positively correlated, within individuals, and - because of assortative matching between spouses. Thus, the inclusion of the difference in fathers' education is likely to pick up a large share of the differences in $h^{f}$ and $g^{f}$, and may also pick up parts of $h^{m}$ and $g^{m}$ that are not differenced out. We also include grandparents' education, which may partly account for assortative matching on unobserved endowments. In addition to estimating equation (2) using children of twin mothers (for $\delta_{1}$ ) and of twin fathers (for $\delta_{2}$ ), we also provide separate estimates based on first cousins from the mothers' and fathers' side (irrespective of whether the parents are twins).

The parameters of interest in this approach are identified from twins choosing different levels of education. Such differences may not be random. In this case, with remaining unobserved heterogeneity within twin pairs, even if $\Delta h^{m}=0$, it is commonly argued that family fixed effect estimates such as those from (2) do not necessarily reduce the bias (Griliches, 1979; Bound and Solon, 1999). Any nonrandomness in schooling choice within twin pairs could be because of differences in $g$ in our model, e.g., if twins are treated differently by parents or if they are different by birth. Behrman and Rosenzweig (2004) argue that this type of heterogeneity can to some extent be explained by birth weight differences within monozygotic twin pairs in the US, and this is also supported by Black, Devereux and Salvanes (2007) using monozygotic twins for Norway. As argued by Bound and Solon (1999), the fixed effect estimate of the model $Y=\alpha+\delta S+v$, where $\delta, \operatorname{cov}(S, v)$ and $\operatorname{cov}(\Delta S, \Delta v)$ are all assumed to be positive, is closer to the true parameter $\delta$ if and only if:

$$
\frac{\operatorname{cov}(\Delta S, \Delta v)}{\operatorname{var} \Delta S}<\frac{\operatorname{cov}(S, v)}{\operatorname{var} S},
$$


i.e., the endogenous variation in educational attainment comprises a smaller fraction of the between-twin variation in schooling than it does of the between-family variation. In our case, we will have a composite error term, capturing differences in $h^{f}$, the $g$ 's and $\varepsilon^{c}$. As argued earlier, conditioning on (the difference in) fathers' education is likely to remove some of the remaining differences in $h^{f}$ and $g^{f}$ which means that the fixed effect estimate of $\delta_{1}$ is closer to the true value if and only if:

$$
\frac{\operatorname{cov}\left(\Delta S^{m}, \Pi_{1} \Delta g^{m}+\Delta \varepsilon^{c}\right)}{\operatorname{var} \Delta S^{m}}<\frac{\operatorname{cov}\left(S^{m}, \Pi_{1} g^{m}+\varepsilon^{c}\right)}{\operatorname{var} S^{m}},
$$

It is hard to argue theoretically that (4) holds, simply because the variance in schooling differentials for twins is much lower than population variance (in our case, one-fifth). However, we can reasonably assume that both correlations (e.g. bias terms) are non-negative. If the fixed effect strategy provides a lower estimate, we have established a tighter upper bound on the true parameter. As highlighted by Bound and Solon (1999), this argument only holds in the absence of measurement error because the attenuation bias due to imprecise measure of parental education is amplified using the fixed effects strategy. We return to this issue in Section 6.

\subsection{Adopted children}

Assuming that adopted children are allocated to rearing parents at random, there is no association between unobservable heritable endowments of rearing parents and their adopted children $\left(\Gamma_{1}=\Gamma_{2}=0\right)$. For adopted children, we have:

$$
Y^{c}=\delta_{1} S^{m}+\delta_{2} S^{f}+\Pi_{1} g^{m}+\Pi_{2} g^{f}+\lambda X+\varepsilon^{c},
$$

where the important thing to notice is that by using adoptees, genetic effects are eliminated. Compared with equation (2), we see that the child-rearing endowments for both parents still remain. There are reasons to believe that these endowments are 
positively correlated with parental educational attainment, also for adoptive parents. However, adoption practice may influence how parental characteristics are correlated. Imagine that adoptive parents are (self-)selected with respect to a minimum value of an index of education and child-rearing skills. Around the threshold, education and child-rearing skills will be negatively correlated. To check the importance of selective adoption practice we provide estimates based on a sample of biological relations in adopting families

\section{Institutions and data}

\subsection{Norwegian education system}

Norwegian compulsory education starts at age six, lasts for 10 years and consists of primary school ( $1^{\text {st }}$ to $7^{\text {th }}$ grade) and lower secondary school ( $8^{\text {th }}$ to $10^{\text {th }}$ grade) Norwegian municipalities operate schools to provide compulsory education, and the vast majority (98 per cent) of pupils attend public, local schools during compulsory schooling. This study focuses on performance in the final written examination at the end of $10^{\text {th }}$ grade. The exam mark is based on a five-hour test in one of the core subjects of mathematics, Norwegian or English. All pupils in the country do the same (subject-specific) test. Pupils are randomly allocated to subjects, and the marking is anonymous and done by external examiners. The test is "high-stake" and forms part of the basis for admission into upper secondary education.

\subsection{Adopted children}

Adoption of foreign-born children by Norwegian parents started in the mid 1950s, triggered by the high number of civilian casualties in the Korean War. By around 
1980, the number of inter-country adoptions outnumbered domestic adoptions and now constitutes close to 80 per cent of the total. The country of origin mix has changed over time. While the cohorts in the 1960s and early 1970s were dominated by children from South Korea, a larger variety of donating countries in Latin America and Asia emerged during the 1970s, e.g., Colombia. The strategy of using adopted children to identify intergenerational effects of schooling only works when parents and children are matched randomly (Björklund, Lindahl and Plug, 2006). In our case, family placements happened abroad with limited information about the child and few opportunities for potential parents to choose. We focus on children born in South Korea because recent studies have argued that random family assignment is likely to hold for this group. Sacerdote (2002, 2007) shows that adoptions to the US from Korea around 1970, administered by Holth International, were characterized by random matching, where the children were allocated to parents on a first come first served basis. As the Norwegian organization operating in Korea ("Verdens Barn”) cooperates closely with Holth and interacted with the same local authorities, there is hardly any reason to believe that the matching should be different in our data.

Adoptions in Norway have been regulated by law since the introduction of the 1917 Law on Adoptions (revised in 1986). An official approval of an adoption requires that a number of criteria are fulfilled, and the law is based on the principle that an adoption "should be in the interest of the child" and not depend on where in the world the child is born. In the case of inter-country adoptions, limited information about the child is available. Therefore, adults who are allowed to adopt are evaluated according to a list of criteria that are assumed to be important to child development in general. 
Inter-country adoptions have been administered by adoption organizations since the late 1950s. The pecuniary costs of an adoption are non-trivial and the economic support from the Norwegian government is limited. Accreditation regulations and practices add to the self-selection. Several criteria that are supposed to be important regarding child development must be met by the adopting family: the parents must be above 25 years of age and typically less than 45 (no strict upper limit), married for two years or more, with no "serious and permanent" mental or physical health problems, a social network of friends and relatives, a stable economic situation and no criminal record. Parents qualify through a process that includes an extensive written application, interviews and a home visit. There are no explicit earnings-or educational attainment-requirements. However, educational attainment and economic resources are likely to affect the evaluation made by the case-worker and thereby the characteristics of adopting families. Selective placement gives the adoptees, on average, more qualified parents, than children growing up with their biological parents.

Because foundations for cognitive and social skills as well as brain maturation are developed in the early months (see Knudsen et al., 2006 for a cross-disciplinary survey), it is crucial to make inferences on the impact of post-birth environmental factors from the experiences of children adopted early. The logic of the adoption identification strategy builds on the existence of data where the amount of time parents and children spent together is independent of the biological relationship status. ${ }^{6}$ With a trade-off between sample size and the age at adoption restriction, we

\footnotetext{
${ }^{6}$ Whether the environmental effects are related to the period from the date of birth, or start earlier, is not always clear. Adoption studies cannot address the impact of the prenatal environment.
} 
focus on children adopted before their first birthday. Our sample consists of 558 adopted pupils born 1985-1991. ${ }^{7}$ The average age at adoption is 5.2 months.

\subsection{Data}

Our sample covers all pupils who completed compulsory education in Norway $\left(10^{\text {th }}\right.$ grade in lower secondary school) in the graduating cohorts from 2002 to 2007. Individual marks by subject, individual characteristics and family background variables are collected from administrative registers. Because data on family relationships and education is of poorer quality for immigrants, we exclude students with two foreign-born parents. There is no attrition, but a small minority of pupils is dropped from the data set because of missing family information, and a somewhat larger share of the pupils is dropped from the sample because of missing data when schooling levels of grandparents are included as control variables.

The data on exam marks by subjects are collected by the Directorate for Primary and Secondary Education. Marks are awarded on a scale from one to six (higher marks indicating better performance).

From register-based family files, we have information on parents and grandparents (including their personal identifier) of in principle all children in our sample. We can thus identify sisters and brothers (by having the same parents) and their children, and use this to compare the school performance of first cousins. Because we have information on date of birth and year of birth, we can identify twins by having the same parents and being born on the same or adjacent days.

Parents' and grandparents' educational attainment is taken from the National Education Database of Statistics Norway. This database started with self-reported data

\footnotetext{
${ }^{7}$ The number of students born in 1985 and completing secondary school in 2002 is much smaller than for the other years, and thus belong to a small group who finish the year they turn 17 .
} 
from the 1970 census, and has since 1974 been supplemented primarily by the educational institutions reporting directly to Statistics Norway, thereby minimizing any measurement error because of misreporting. In our sample, about 90 per cent of the mothers and 83 per cent of the fathers have education data reported from the institutions, while the remaining parents have census data. The information in census data is considered to be very accurate; there are no spikes or changes in the education data from the early to the later cohorts.

As the permanent economic resources of the family may be more important than current income during the final school years, family income is defined as the sum of the father's and mother's taxable labour income during the 10 years prior to graduation from lower secondary school, regardless of marital status. We include dummies for year of graduation and gender (for the pupils) and the age of parents in our analysis.

In some of the analyses, we include labour market experience in our sample. Our experience measure is constructed using a comprehensive database of labour market earnings histories with annual information back to 1967. These earnings histories form the basis of the calculation of public pensions. We assign full experience for a given year to parents with registered income above a certain (deflated) threshold, partial experience for lower income, and zero experience for low income. Experience is then summed over years to obtain total experience. This will be negatively related to time at home with own children. An important exception is the case of maternity leave, which is paid and registered as labour income. Thus, we interpret mothers (or fathers) on paid leave as working. The summary statistics of the variables used are given in Table 1. 


\section{Results}

\subsection{Observed family characteristics}

We start in Table 2 by presenting the standard OLS regressions of the intergenerational relationship between children's exam score and mother's and father's education, for all children that graduated from lower secondary school in Norway in the years from 2002 to 2007. Note that in addition to parents' education, we include a number of control variables in the regression: gender, graduation cohort, exam subjects, and age of parents by means of dummy variables.

As expected, there is a strong and significant relationship between parents' education and children's school performance. The relationship is of the same order of magnitude for mother's and father's education. In columns (1) and (2), we see that one extra year of schooling for either of the parents, without controlling for the level of schooling of the other parent, is associated with an increase in the exam score of around 0.1 grade points (on a scale from one to six, with a standard deviation of around 1). From column (3), we see that when we include both parents' education and thus control for the effect of assortative matching on schooling, the coefficients for individual parental education is reduced by about 30 per cent. The correlation between parents' years of schooling is 0.38. Even if matching in the marriage market is clearly non-random, correlation in years of schooling between partners is about 0.15 lower in Norway than in countries such as the UK and the US where schooling correlation is typically around 0.55 (Raaum et al., 2007).

When we include family earnings over the 10 years prior to graduation from lower secondary school (column (4)), the relationship between parental education and children's school performance is slightly weaker, reflecting a strong relationship between family income and parental education but a fairly loose association between 
family income and educational performance. In column (5), we also include grandparents' education and the estimates provide an even tighter upper bound on the causal effects. By including the educational attainment of the parents' parents, we partly control for genetic endowments and unobserved factors that are transmitted culturally across generations. This specification also acknowledges that assortative matching extends beyond correlated education among spouses as people from welleducated families tend to marry each other. ${ }^{8}$ Thus, even education of in-laws serve as proxies for unobserved characteristics that may affect child performance and correlate with parental education. By including attainment of grandparents, the effects of parents' education are reduced even more. Interestingly, it is the grandmothers' education that is strongest, although grandfathers' education is also significant. ${ }^{9}$

In total, by including a rich set of family characteristics, the coefficients on parental education are reduced by nearly one half compared with the regression where only mothers' and fathers' education were included individually. Even though the most detailed specifications in Table 2 to some extent control for, or at least mitigate, the effects of the unobserved components in equation (1), our estimates in column (5) can only be interpreted as tighter upper bounds because the estimated parameters potentially capture inherited endowments as well as other unobservable child-rearing skills that are correlated with education. Finally, parental education effects may reflect sorting into neighbourhoods and schools, but Norwegian evidence suggests that local conditions have limited impact on educational outcomes of children when

\footnotetext{
${ }^{8}$ Raaum et al . (2007) show that educational attainment of the parents of partners-in-law are highly correlated, although less so in Norway than in the US and the UK. Educational attainment is also correlated with the earnings of the father-in-law.

${ }^{9}$ Because the number of observations was reduced somewhat when grandparents' education was included, we replicate the regression in column (4) for this restricted sample. The results are reported in column (6), and are very similar to those obtained using the full sample.
} 
we condition on observable family characteristics such as parental education and income (see Raaum, Salvanes and Sørensen, 2006).

\subsection{Cousins - children of siblings}

The next step in our test procedure is to restrict the sample to cousins, where mothers are siblings or fathers are siblings, respectively. The idea is that by using grandparent fixed effects, comparing the school performance of cousins and relating it to differences in the schooling of their parents (who are siblings); we extend the control for unobserved family characteristics. Siblings share both some genetic endowment and childhood environment, which in general correlate with educational attainment and unobserved factors that influence the school performance of their children.

In Table 3, we present the results for the samples where a mother and a father are siblings. ${ }^{10}$ From columns (1) and (4), first note that the estimates of the impact of parents' education, when identified from differences in the level of schooling within pairs of sisters who are mothers and pairs of brothers who are fathers, respectively, are nearly halved relative to those in column (3) in Table 2, which is the relevant “conditional on observables” comparison. These results clearly indicate that at least a part of the positive intergenerational correlation in educational outcomes is driven by genetic factors, inherited skills or cultural factors shared by members of a "dynasty”. By including these family fixed effects, the upper bounds are tightened further compared with what is achieved by including the educational attainment of grandparents. Comparing Tables 2 and 3, we see that the estimate for mother's education drops from 0.056 to 0.036 while the estimate for father's schooling changes from 0.052 to 0.041 . Table 3 also shows that when mothers are sisters, the coefficient

\footnotetext{
${ }^{10}$ For comparison, we include the OLS results for these samples in the Appendix, Table A1, and they turn out to be very similar to the results for the population at large, as reported in Table 2.
} 
on father's education remains large. Because sisters tend to marry men who are similar with respect to traits that affect the outcomes of their children and are correlated with parental schooling, the coefficient on father's education is somewhat lower relative to the OLS estimate and vice versa when fathers are siblings. This point is also underlined by the results in columns (3) and (6). When father's parents' education is introduced, there is a reduction in the effect of father's education in the sample when mothers are siblings, and vice versa when controlling for mother's parents' education in column (6). Again, including family income does not change the results substantially, as is seen from columns (2) and (4).

\subsection{Cousins-children of twins}

Going one step further, we now restrict the samples to pupils whose mothers or fathers are same-sex twins. Dizygotic (DZ) twins are ordinary siblings born at the same time, and have presumably been exposed to a more similar childhood environment than brothers and sisters in general. Monozygotic (MZ) twins share both genes and childhood environment (leaving the controversial issue about reinforcing or compensating parental treatment aside). We report results for the offspring of twin mothers and twin fathers based on the same type of estimations presented in Behrman and Rosenzweig (2002), except that we cannot distinguish between DZs and MZs. Our samples of same-sex twins are a mix of the two types with about an equal share. It is useful to compare the twin results both with the "conditional-on-observablesestimates” in Table 2 and the full cousin samples of Table 3. By focusing on twin offspring, there is less genetic variation that may correlate with parental education. ${ }^{11}$

\footnotetext{
${ }^{11}$ There are of course differences between siblings and twins with respect to the similarity of home environment. Twins grew up at the same time in the family and thus were exposed to the same positive or negative income and other shocks to the family.
} 
Columns (1) to (3) in Table 4 present the results for the sample of children of mothers who are twins, and the next three columns present the results for children of twin fathers. $^{12}$

Consider first the effect of mother's schooling in the first three columns of Table 4. When we include both mother's and father's education, taking into account both mothers' endowment and the effect via fathers' schooling through assortative matching, we obtain an insignificant negative effect of mother's education on children's school performance. The coefficient for father's education is positive and significant, and similar to the corresponding results in Table 3. The same results basically hold when we control for family income and for grandparents' education. Note, however, that the relationship between family income and children's school performance is stronger than in the previous samples. The interpretation of these results is that among mothers with about the same pre-school human capital in terms of genes and other dimensions of family background, conditional on assortative matching, those who obtained more education do not have children who do better in school than the children of those mothers who obtained less. The lack of an effect for mother's education on children's school performance using the within twin mothers estimator is the same as for the MZ twin sample in Behrman and Rosenzweig (2002).

Similar results are obtained when using the sample of twin fathers and identifying the effect of father's schooling, presented in columns (4) to (6). Among fathers with very similar preschool human capital by the fact that they are twins, controlling for assortative matching, those with more education do not have children who perform significantly better in school.

\footnotetext{
${ }^{12}$ The OLS results for this sample are given in Table A2 in the Appendix, and the estimated results are very similar to those presented in Table 2 .
} 


\subsection{Adopted children}

Our second identification strategy builds on random allocation of children across family environments and looks at the relationship between the education levels of adopting (rearing) parents and the schooling performance of their foreign-born adopted children. Given the reasonable assumption of random placement for our sample of early adopted children from Korea, there is no association between the unobservable heritable endowments of parents and those of their adopted children. However, the estimates may still be biased because of correlations between parental education and unobserved family characteristics such as child-rearing skills within the sample of adoptive parents.

The results for the adopted children are presented in the first four columns of Table 5. Columns (1) and (2) include no other family characteristics, and there is a positive and statistically significant association between parental education and child school performance for both mother and father. The coefficients are close to 0.03 , which is only about one-third of the effect for biological relations using the full population sample in Table 2. Including the schooling of the other parent as well as long-run family income reduces the coefficients to 0.022 for mother's schooling and to 0.019 for the father's (see columns (3) and (4)). Note that the effect of father's education is no longer significant.

One might suspect that the selection of adopting parents creates a negative bias in the effect of parental education. If lack of formal education can be compensated by other factors in the approval of adopting parents, this may introduce a different correlation between parental education and unobserved family factors (such as rearing skills) in adopting families. To the extent that these unobserved factors are common within families, this bias should also be reflected in the intergenerational schooling relationship between siblings of adopting parents and their biological 
offspring. In columns (5) to (8) in Table 5, we report the comparable estimates for the children of the adopting parents' siblings. ${ }^{13}$ The associations between parental education and school performance of children are equally strong for this sample as for the population at large (see Table 2). This suggests that there is negligible bias because of selective adoption practices.

Ideally, when estimating the impact of post-birth factors by means of adoptees, one should only focus on children placed in their new environment as close to birth as possible. Even our age restriction of less than one year at the date of adoption may not be sufficient. We have added interaction terms between age at adoption and parental education, but these turn out to be insignificant. ${ }^{14}$

In sum, using a large sample of Norwegian parents and children, strong correlations are found between mothers' and fathers' education and children's exam performance. Our two different identification strategies with the same data in terms of cohorts and variables arrive at somewhat different results across methods. More precisely, in cross-sectional specifications when controlling for a rich set of family background variables including assortative matching, and when comparing cousins, the effect of mother's education on children's educational performance disappears when using the mothers as twins. Using the fathers as twins, the point estimates are reduced less and are still positive, but imprecisely estimated and not statistically significant. Hence, there is no support for a significant causal effect of mothers' education using the COT approach. Using adopted children, however, we do find an effect of mother's education on children's school performance. ${ }^{15}$ By and large this

\footnotetext{
${ }^{13}$ Ideally, we would have preferred to look at biological offspring (siblings) in adopting families as in Raaum and Westlie (2008), but the sample is too small.

${ }^{14}$ These results contrast those found in Raaum and Westlie (2008), where there is a negative interaction between mother's education and age at adoption.

${ }^{15}$ As a comparison to the results in Oreopoulos, Page and Stevens (2006), we also estimated the effect of the sum of parents' education. For adoptees we obtain exactly the sum of the coefficients of the
} 
also reflects the previous literature using adoptees, in which there is a weak but positive effect of mother's education (Plug, 2004; Björklund, Lindahl, and Plug, 2007; Holmlund, Lindahl and Plug, 2008). ${ }^{16}$ It is also a priori expected that these two strategies for controlling for inherited ability provide different results. The twin strategy assumes that both unobserved inherited endowments and child-rearing endowments are differenced out, whereas the adopted children approach only accounts for genetically transmitted ability. The results are also consistent with the small effects found when using educational reforms as an instrument for education. In the next section, we will report a series of robustness checks as well as test and discuss whether non-linear parental education effects can explain these findings.

\section{Robustness checks}

\subsection{Measurement error in education}

First, we want to check whether our results are robust to measurement error, i.e., does the causal effect decline because OLS provide upward biased estimates or due to measurement error? If misrepresentation of parental education is a serious problem in our analysis, it is well-known that the attenuation bias from classical measurement error is inflated by the fixed effect estimator, simply because noise constitutes a larger share of the observed schooling variation. ${ }^{17}$ In general, we expect that our education variables are measured correctly, because they are based on administrative data from the Norwegian register of education. All educational institutions report completed

individual parents' education. For the children of twins the estimated effect of the sum is slightly larger than the sum of the individual effects. Note, however, that only the parent which is a twin is identified here so this is an expected result. We still get much larger effects within fathers than within mothers.

${ }^{16}$ However, this is in contrast to Sacerdote (2002), (2007).

${ }^{17}$ If classical measurement errors are positively correlated within families (i.e., between siblings), the attenuation bias using the fixed effect may not exceed that from OLS. 
educational activities by every individual to this register. Hence, larger share of the data is not self-reported as in many other cases, so we would expect very little measurement error. Parental education is defined as the highest qualification obtained and attainment is converted into years of schooling by the statutory years needed to acquire it. However, we cannot a priori rule out that parental education is measured with error. If so, we expect the error to be classical, because we do not think that, for instance, the error increases with the education level leading to reversion to the mean.

A standard solution to the potential measurement error problem is to use an alternative independent measure such as the cross-reported education by twins in Ashenfelter and Krueger (1994). We do not have access to a comprehensive, independent source of education information for all the parents. Based on assortative matching evidence, we use branches of the family tree that are genetically unrelated. ${ }^{18}$ Consider cousins with twin mothers. The twins' partners will typically not have the same ancestors (in recent generations) as the cousins and their parents. Hence, we use brothers/sisters-in-law to the parents in our study and their schooling as instrumental variables for parental education. We find a significant schooling correlation between schooling of sisters- and brothers-in-law that justifies the first stage.

The IV estimates based on the samples of cousins are provided in Table 6a. In columns (1) and (3), we see that the cross-sectional estimates without grandparent fixed effects are actually doubled from about 0.07 to 0.14 . Assuming our instrument is valid, these large effects indicate serious measurement error, which means that our within family estimates are seriously biased towards zero. Note also that the doubling holds for both mother’s and father's education, suggesting equal measurement error across gender. Thus, if measurement error rather than unobserved ability caused the

\footnotetext{
${ }^{18}$ This approach is similar to that of Bingley, Christensen and Walker (2009), who use education of the co-twin partner as an instrument in a study of return to schooling.
} 
disappearing effects of mother's schooling in Table 4, we would expect that the effects of mother's and father's education were equally affected by family fixed effects. However, as the coefficient of the mother drops considerably more (see Table 4) than for the father, it appears that measurement error (alone) cannot explain our results in Table 4. This conclusion is strengthened by columns (2) and (4) in Table 6a, as the estimates with grandparent fixed effects are reduced by about one-third for mother's schooling and even more for father's schooling.

However, the estimated effects presented in Table 6a, based on all sibling parents and using the IV estimator, are highly significant and close to the unconditional OLS cross-sectional estimates. As discussed carefully in Neumark (1999), even if measurement error is corrected for by using an IV estimator for twin differences, any remaining ability bias (e.g., differences in rearing capacity correlated with educational attainment for twins) may be exacerbated by the IV approach. The identifying assumption in the IV approach is that education of the in-law uncles/aunts who are siblings of the co-twin's partner is not directly associated with the pupils' ability. This is hardly true across families, and is even questionable considering differences between cousins with twin parents. As discussed, if there is heterogeneity in twins' schooling related to birth weight differences or differences in how they were brought up, the ability difference will not disappear using within twin pair differencing and will possibly be directly passed on to their children. Due to positive non-random marriage matching, we may also expect some correlation between our instrument and the error term in the achievement equation. Therefore, the IV estimator in this context is expected to provide biased estimates of the effects of mother's and father's education. Because we can sign the bias as non-negative under reasonable assumptions, the within family IV estimates will potentially provide 
tighter upper bounds on the causal effects of parental education. In this respect, our estimates based on cousins fail as they are larger than the conditional cross-sectional estimates.

Turning to the sample of cousins with twin parents estimated using IV reported in Table 6b, we see that our original result (reported in Table 4) of an insignificant and negative effect of mother's education remains. From column (2), we see that there is a substantial drop when we estimate within twin parents' families, supporting the conclusion that the causal effect of mother's education is low. The results for cousins with twin fathers are less conclusive, as the estimated effects with and without grandparent fixed effects are similar, but also very imprecise.

\subsection{Different specifications of parents' education}

The mechanism by which parental education influences child outcomes may be poorly represented by a simple additive linear model. A possible explanation of our result of a weak effect of mothers' education could be that there is a weaker effect of an extra school year for the most educated mothers. To check for this, we split education in two - up to and above high school—for both fathers and mothers. The results are reported in columns (1) to (4) of Table 7a. As we can see, there is some indication of the opposite, particularly for mother's education where the marginal effect of an extra schooling year is larger among the more highly educated. Hence, a strong non-linearity driven by smaller effects of the highly educated cannot explain the small or zero causal effects of parents’ education.

Next, we consider two issues with respect to how mother's and father's education are related, over and above controlling for assortative matching in a linear fashion. First, we introduce the possibility that parents' education levels are complements or substitutes by including an interaction term of parental education. 
The results presented in column (5) reveal a small positive interaction effect, providing weak support for the hypothesis that mothers' and fathers' education are complements. However, the coefficient turns significantly negative when we include grandparents' level of schooling in the model (see column (6)). One possible explanation for the latter is that through assortative matching in the parents' generation, the education of the spouse is measuring the part of family background that extends beyond their own years of schooling and was reflected earlier in the impact of grandparents' schooling (see Table 2). However, introducing interaction terms does not have a large impact on the separate coefficients of mother's and father's education.

The second non-linearity issue we address is more directly related to the result that mother's education seems unimportant. If the highest education among the parents was the main contributor in the human capital production function and thereby most important for children's schooling outcomes, the schooling of the mother would be less important simply because the father's education has traditionally been the highest of the two. In our sample, in 41 per cent of the cases, fathers have a higher education level than mothers, in 24 per cent it is equal, and in 35 per cent mothers have a higher level. We now specify the model to allow for the different effects of a parent's schooling with respect to whether it is the highest or the lowest of the parents. The results reported in column (7) in Table 7a do suggest that there may be something to this explanation. The relationship between a parent's education level and child school performance is significantly stronger for the parent with the highest education. However, when we do a fixed effect estimation of this specification on the twin's sample, cf. Table 7b, there is no evidence of such an effect. Again, this type of non-linearity does not explain the lack of an effect of mother's education. 
It could be that couples within certain fields of education and occupations, who are highly educated but also work very hard, reduce the effect of parental education to zero. To check this, we split mother's and father's education into fields of study, and augmented the various specifications reported above with these variables. The results (not reported) were very similar with respect to the effects of length of schooling, and there were no systematic differences between fields of education. In summary, we do not find any support for non-linearities and different effects between specific fields of study explaining the small effect of parental education on children's scholastic outcomes.

\section{Does the high labour force participation of highly educated mothers hurt their children's school performance?}

Is the reason for the absence of an effect of mother's education that highly educated mothers are also mothers that work more and therefore spend less time with their children? If transmission of human capital from parent to child requires much time spent together, the total effect of a highly educated mother with long working hours in the labour market could be small.

Indeed, there is a positive correlation, 0.28 , between years of schooling and

years of work experience for mothers in our sample. For fathers, the correlation is only 0.18 . For the twin samples, this correlation is lower, 0.12 for mothers who are twins and 0.05 for fathers who are twins. There is also a positive correlation between the work experience of mothers and fathers, 0.16. In Table 8, we present more details on the relationship between mothers' and fathers' years of working by education and by children's age. It is clear that mothers' work is monotonically increasing in education, independent of the age of their children. The same is true for fathers. It is 
also clear that mothers'/fathers' participation in work is increasing in their spouse's education level.

In Table 9, we report the results from regressions where we include work experience of parents as control variables. In Table 9a, we report cross-sectional results of intergenerational regression on mother's (father's) education on children's school performance where we allow for the effect of mother's (father's) experience to vary by when it was obtained in the life of the child. The first thing we notice is that the relationship between parents' education and children's school performance is more or less unaffected by including experience. Surprisingly, there is if anything a stronger positive effect of working more for mothers (and fathers) when children are aged between zero and one than at higher ages. In Table 9b, we report the fixed effect estimates for the twin sample. Again, the main results with respect to the effect of parents' schooling are not affected by controlling for how much mothers and fathers are working.

We should note, however, that our findings do not imply that spending more time in the labour market improves the school performance of their children. It may also reflect some unobserved "capacity” that drives both labour force participation and human capital transmission. The literature on the effect of parental work on children's outcomes such as education is not conclusive, and the effect depends on the context or alternative (Waldfogel, 2006). Studying an extension of the fully covered maternity leave period and using Norwegian data, Carneiro, Løken and Salvanes (2009) find that there is a positive effect of not working during the first year of a child's life. However, the effect is much stronger among low educated mothers, supporting our results here. 
The results are consistent with evidence from time use surveys, suggesting that there is a positive relationship between a mother's education and the time spent on active childcare (excluding, e.g., general housework with the child present). See Guryan, Hurst and Kearney (2008) for US and international evidence, Bloemen and Stancanelli (2008) for a theoretical and empirical analysis using French data and Kitterød and Lyngstad (2005) for a study using Norwegian data. This relationship holds both unconditionally and when controlling for employment status. A pattern that seems to emerge from these studies is that working mothers with high education spend less time on non-market work and leisure than working mothers with low education, leaving more time available to spend with their children.

\section{Conclusion}

Within the same population and data set, we use two different empirical strategies to identify the causal effect of parents' education on their children's school exam scores at age 16. One is to use adopted children who only share parents' environments and not their genes, and the other is to use parent twins where both parents' environment and part of their genes are shared, as the basis for identification.

We find strong cross-sectional relationships between parental education and their children's school performance, but the estimated causal effects vary across identification strategies. Among children adopted early, there is a small and statistically significant, effect of mother's education. The effect of father's education is of similar magnitude, but not statistically significant. Using educational variation between parents who are twins, there are no significant effects of the mother's or the father's education. The results are thus in line with the evidence from the literature that identification strategies matter. Even under several robustness checks on the non- 
linear effect of education, the same results hold. A careful check suggests that the results are not driven by measurement error in parental education.

Given the surprisingly small or non-existent effect of mother's education, this paper made a first step in advancing our knowledge of why there is no causal effect on children's educational performance of mother's education, or why more education does not make women "better" mothers in this respect. We investigate to what extent highly educated mothers work more and if this may explain the weak effect of mother's schooling. More educated mothers work more, but we find no detrimental effect on children's education. This result is also supported by time use studies, showing that more educated parents spend more time with their children. 


\section{References}

Antonovics, K., and A. S. Goldberger (2005), Do Educated Women Make Bad Mothers? Twin Studies and the Intergenerational Transmission of Human Capital, The American Economic Review, 95 (5), 1738-1744.

Ashenfelter, O. and A. Krueger (1994), Estimates of the Economic Return to Schooling from a New Sample of Twins, The American Economic Review, 84 (5) 1157-1174.

Baum, C.L. (2003), Does Early Maternal Employment Harm Child Development? An Analysis of the Potential Benefits of Leave Taking, Journal of Labor Economics, 21, 409-448.

Behrman, J. R. (1997), Mothers Schooling and Child Education: A Survey, PIER Working Paper 97-025.

Behrman, J. R. and M. Rosenzweig (2002), Does Increasing Women’s Schooling Raise the Schooling of the Next Generation?, The American Economic Review, 91(1), 323-334.

Behrman, J. R. and M. Rosenzweig.(2004), Returns to Birthweight, Review of Economics and Statistics, 86(2), 586-601.

Belzil, C. and J. Hansen (2003), Structural Estimates of the Intergenerational Education Correlation, Journal of Applied Econometrics, 18(6), 679-690.

Berger, L. M., J. Hill, and J. Waldfogel (2005), Maternity Leave, Early Maternal Employment and Child Health Development in the US, The Economic Journal, 115, 29-47.

Bingley, P., K. Christensen, and V. Myrup Jensen (2009), Parental schooling and child development: Learning from twin Twin Parents, The Danish National Centre for Social Research Working Paper 07:2009.

Bingley, P., K. Christensen and I. Walker (2009), Decomposing the Changing Returns to Schooling by Explaining Twin Differences, The Danish National Centre for Social Research Working Paper 076:2009.

Björklund, A., M. Lindahl and E. Plug (2006), The Origins of Intergenerational Associations: Lessons from Swedish Adoption Data, Quarterly Journal of Economics 121(3), 999-1028. 
Black, S. E., P.J. Devereux and K.G. Salvanes (2005), Why the Apple Doesn't Fall Far: Understanding Intergenerational Transmission of Human Capital, The American Economic Review, 95 (1), 437-449.

Black, S. E., P.J. Devereux and K.G. Salvanes (2007), From the Cradle to the Labor Market? The Effect of Birth Weight on Adult Outcomes,. Quarterly Journal of Economics, 122 (1), pp. 409-439.

Bloemen, H. and E. Stancanelli, (2008), How Do Parents Allocate Time? The Effects of Wages and Income, IZA Discussion Papers 3679.

Bound, J. and G. Solon (1999), Double Trouble: On the Value of Twins-Based Estimation of the Returns to Schooling, Economics of Education Review, 18, 169-182.

Carneiro, P. and J. Heckman (2003), Human Capital Policies, in J. Heckman, and A. Krueger (Eds.), Inequality in America: What Role for Human Capital Policies. MIT Press.

Carneiro, P., C. Meghir and M. Parey (2007), Maternal Education, Home Environment and the Development of Children and Adolescents, IZA DP No. 3072.

Carneiro, P., K. Løken, and K.G. Salvanes (2009), A Flying Start or no effect? Long Term Consequences of Time Investment in Children during their first Year of Life, Mimeo, Norwegian School of Economics.

Dearden, L., S.Machin and H.Reed (1997), Intergenerational Mobility in Britain, The Economic Journal, 107, 47-66.

D’Onofrio, B.M. (2005), The children of twins design, in In B. Everitt \& D. Howell (Eds.), Encyclopedia of Behavior Statistics. pp. 256-258. New York: Wiley.

Dustmann, C. and U. Schönberg (2008), The Effect of Expansions in Maternity Leave Coverage and Children's and Mothers' Long-Term term Outcomes, IZA DP No. 3605

Griliches, Z. (1979), Sibling Models and Data in Economics: Beginnings of a Survey, Journal of Political Economy, 87, 37-64.

Guryan, J, E. Hurst, and M. Kearney (2008), Parental Education and Parental Time with Children, Journal of Economic Perspectives, 22(3), 23-46.

Haveman, R. and B. Wolfe (1995), The Determinants of Children Attainments: A Review of Methods and Findings, Journal of Economic Literature, 33(4), 1829-1878. 
Heckman, J. (2006), Skill Formation and the Economics of Investing in Disadvantaged Children, Science, 312, 1900-1902.

Heckman, J and D. Masterov (2007), The Productivity Argument for Investing in Young Children, NBER WP No. 13016.

Holmlund, H., M.Lindahl, and E.Plug (2008), The Causal Effect of Parent's Schooling on Children's Schooling: A Comparison of Estimation Methods, IZA DP No. 3630.

Kitterød, R. H. and T.H. Lyngstad (2005), Diary versus Questionnaire Information on Time Spent on time spent on housework - The Case of Norway, International Journal of Time Use Research , 2(1), 13-32.

Knudsen, E., J. Heckman, J. Cameron and J. P. Shonhof (2006). Economic, Neurobiological, and Behavioural Perspectives on Building America's Future Workforce. Proceedings of the National Academy of Sciences, 103(27), 10155-10162.

McNally, S. and E.Maurin (2008), Vive la Revolution! Long-term Educational Returns of 1968 to the Angry Students, Journal of Labor Economics.

Neumark, D. (1999), Biases in Twin Estimates of the Return to Schooling, Economics of Education Review, Vol. 18(2), pp 143-148.

Oreopoulos, P., M.E. Page, and A.H. Stevens (2006), Does Human Capital Transfer from Parent to Child? The Intergenerational Effects of Compulsory Schooling, Journal of Labor Economics, 24 (4), 729-760.

Page, M (2006), Father’s Education and Children’s Human Capital: Evidence from the World War II GI Bill, Working Paper 06-33, UC Davies.

Plug, E. (2004), Estimating the Effect of Mother's Schooling on Children's Schooling Using a Sample of Adoptees,. The American Economic Review, 94(1), 358368.

Raaum, O., K.G. Salvanes and E.Ø. Sørensen (2006), The Neighbourhood is not what it used to be, The Economic Journal, 116 (1), 278-300.

Raaum, O., B.Bratsberg, K. Røed, E.Österbacka, M.Jäntti, T.Eriksson and R. Naylor. (2007), Marital Sorting, Household Labor Supply, and Intergenerational Earnings Mobility across Countries, The B.E. Journal of Economic Analysis \& Policy., 7 (2), (Advances).

Raaum, O. and L.Westlie (2008), More than Genes: Intergenerational schooling Transmission in adopting families, Mimeo. Frisch Centre. 
Sacerdote, B. (2002), The Nature and Nurture of Economic Outcomes, The American Economic Review, 92(2), 344-348.

Sacerdote, B. (2007), How Large are the Effects from Changes in Family Environment? A Study of Korean American Adoptees”. Quarterly Journal of Economics, 122 (1), 119-157.

Waldfogel, Jane (2006). What Children Need. Cambridge. MA: Harvard University Press. 


\section{Tables}

Table 1A. Descriptive statistics, for all non-adopted students.

\begin{tabular}{|c|c|c|c|}
\hline & \# observations & Mean & $\begin{array}{l}\text { Standard } \\
\text { deviation }\end{array}$ \\
\hline Gender & 271452 & 0.490 & 0.500 \\
\hline Father's age & 271452 & 46.517 & 5.534 \\
\hline \multicolumn{4}{|l|}{ Father's years of work: } \\
\hline At child age $6<$ age $<16$ & 271452 & 9.219 & 1.825 \\
\hline At child age $0<$ age $<3$ & 271452 & 2.820 & 0.568 \\
\hline At child age $3<$ age $<6$ & 271452 & 2.816 & 0.604 \\
\hline Father's years of schooling & 271452 & 13.030 & 2.919 \\
\hline Father's father's age & 266088 & 78.486 & 9.803 \\
\hline Father's father's schooling & 253707 & 9.284 & 2.668 \\
\hline Father's mother's age & 268393 & 74.885 & 9.169 \\
\hline Father's mother's schooling & 261495 & 8.549 & 1.836 \\
\hline Exam in mathematics & 271452 & 0.389 & 0.487 \\
\hline Exam in Norwegian, primary form & 271452 & 0.231 & 0.422 \\
\hline Exam in Norwegian, secondary form & 271452 & 0.219 & 0.414 \\
\hline Exam score & 271452 & 3.441 & 1.054 \\
\hline Log of family income 10 years prior to exam & 271392 & 6.116 & 0.585 \\
\hline Mother's father's age & 268491 & 75.345 & 9.684 \\
\hline Mother's father's schooling & 258448 & 9.342 & 2.628 \\
\hline Mother’s mother’s age & 270192 & 71.697 & 8.977 \\
\hline Mother's mother's schooling & 264667 & 8.645 & 1.827 \\
\hline Mother's age & 271452 & 43.730 & 4.914 \\
\hline \multicolumn{4}{|l|}{ Mother's years working: } \\
\hline At child age $6<$ age $<16$ & 271452 & 7.752 & 2.993 \\
\hline At child age $0<$ age $<3$ & 271452 & 1.916 & 1.215 \\
\hline At child age $3<$ age $<6$ & 271452 & 1.993 & 1.248 \\
\hline Mother’s schooling & 271452 & 12.849 & 2.922 \\
\hline
\end{tabular}


Table 1B. Descriptive statistics for the sample when mothers and fathers are siblings.

\begin{tabular}{|c|c|c|c|c|c|c|}
\hline & \multicolumn{3}{|c|}{ Mothers are sisters } & \multicolumn{3}{|c|}{ Fathers are brothers } \\
\hline & $\begin{array}{c}\# \\
\text { observations } \\
\end{array}$ & Mean & $\begin{array}{l}\text { Standard } \\
\text { deviation }\end{array}$ & \# observations & Mean & $\begin{array}{l}\text { Standard } \\
\text { deviation }\end{array}$ \\
\hline Gender & 55870 & 0.491 & 0.500 & 51054 & 0.491 & 0.500 \\
\hline Father's age & 55870 & 46.067 & 4.981 & 51054 & 45.773 & 4.347 \\
\hline \multicolumn{7}{|l|}{ Father's years of work: } \\
\hline At child age $6<$ age $<16$ & 55870 & 9.267 & 1.751 & 51054 & 9.322 & 1.639 \\
\hline At child age $0<$ age $<3$ & 55870 & 2.836 & 0.537 & 51054 & 2.844 & 0.523 \\
\hline At child age $3<$ age $<6$ & 55870 & 2.828 & 0.584 & 51054 & 2.837 & 0.564 \\
\hline Father's years of schooling & 55870 & 12.996 & 2.875 & 51054 & 13.081 & 2.914 \\
\hline Father's father's age & 54982 & 78.127 & 9.361 & 51049 & 76.509 & 8.212 \\
\hline Father's father's schooling & 52767 & 9.206 & 2.621 & 50034 & 9.320 & 2.690 \\
\hline Father's mother's age & 55422 & 74.456 & 8.701 & 51054 & 72.940 & 7.495 \\
\hline Father's mother's schooling & 54306 & 8.516 & 1.805 & 50488 & 8.617 & 1.837 \\
\hline Exam in mathematics & 55870 & 0.389 & 0.487 & 51054 & 0.389 & 0.487 \\
\hline Exam in Norwegian, primary form & 55870 & 0.232 & 0.422 & 51054 & 0.230 & 0.421 \\
\hline Exam in Norwegian, secondary form & 55870 & 0.220 & 0.414 & 51054 & 0.219 & 0.414 \\
\hline Exam score & 55870 & 3.424 & 1.050 & 51054 & 3.446 & 1.053 \\
\hline Log of family income 10 years prior to exam & 55857 & 6.121 & 0.529 & 51044 & 6.135 & 0.535 \\
\hline Mother’s father’s age & 55867 & 73.482 & 8.169 & 50631 & 74.795 & 9.179 \\
\hline Mother's father's schooling & 54854 & 9.271 & 2.573 & 49106 & 9.323 & 2.591 \\
\hline Mother’s mother’s age & 55870 & 69.882 & 7.443 & 50925 & 71.137 & 8.443 \\
\hline Mother's mother's schooling & 55294 & 8.662 & 1.788 & 50116 & 8.635 & 1.798 \\
\hline Mother's age & 55870 & 43.237 & 4.235 & 51054 & 43.285 & 4.410 \\
\hline \multicolumn{7}{|l|}{ Mother's years of work: } \\
\hline At child age $6<$ age $<16$ & 55870 & 7.761 & 2.954 & 51054 & 7.759 & 2.963 \\
\hline At child age $0<$ age $<3$ & 55870 & 1.907 & 1.217 & 51054 & 1.898 & 1.219 \\
\hline At child age $3<$ age $<6$ & 55870 & 1.978 & 1.251 & 51054 & 1.980 & 1.250 \\
\hline Mother's years of schooling & 55870 & 12.823 & 2.874 & 51054 & 12.882 & 2.863 \\
\hline Mother's schooling (alt: further replacing) & 55861 & 12.879 & 2.820 & 51048 & 12.945 & 2.801 \\
\hline
\end{tabular}


Table 1C. Descriptive statistics for the sample when mothers or fathers are twins.

\begin{tabular}{|c|c|c|c|c|c|c|}
\hline & \multicolumn{3}{|c|}{ Mothers are twins } & \multicolumn{3}{|c|}{ Fathers are twins } \\
\hline & $\begin{array}{c}\# \\
\text { observations } \\
\end{array}$ & Mean & $\begin{array}{l}\text { Standard } \\
\text { deviation }\end{array}$ & \# observations & Mean & $\begin{array}{l}\text { Standard } \\
\text { deviation }\end{array}$ \\
\hline Gender & 1571 & 0.468 & 0.499 & 1375 & 0.502 & 0.500 \\
\hline Father's age & 1571 & 46.366 & 4.894 & 1375 & 45.941 & 4.357 \\
\hline \multicolumn{7}{|l|}{ Father's years of work: } \\
\hline At child age $6<$ age $<16$ & 1571 & 9.389 & 1.463 & 1375 & 9.391 & 1.525 \\
\hline At child age $0<$ age $<3$ & 1571 & 2.877 & 0.429 & 1375 & 2.853 & 0.516 \\
\hline At child age $3<$ age $<6$ & 1571 & 2.855 & 0.525 & 1375 & 2.859 & 0.537 \\
\hline Father’s years of schooling & 1571 & 13.161 & 2.929 & 1375 & 13.130 & 2.640 \\
\hline Father's father's age & 1542 & 78.846 & 9.225 & 1365 & 79.130 & 8.959 \\
\hline Father's father's schooling & 1482 & 9.393 & 2.787 & 1313 & 9.244 & 2.557 \\
\hline Father's mother's age & 1557 & 74.963 & 8.540 & 1375 & 75.653 & 8.423 \\
\hline Father's mother's schooling & 1520 & 8.563 & 1.934 & 1356 & 8.361 & 1.778 \\
\hline Exam in mathematics & 1571 & 0.395 & 0.489 & 1375 & 0.393 & 0.489 \\
\hline Exam in Norwegian, primary form & 1571 & 0.236 & 0.424 & 1375 & 0.232 & 0.422 \\
\hline Exam in Norwegian, secondary form & 1571 & 0.224 & 0.417 & 1375 & 0.221 & 0.415 \\
\hline Exam score & 1571 & 3.423 & 1.062 & 1375 & 3.447 & 1.056 \\
\hline Log of family income 10 years prior to exam & 1571 & 6.172 & 0.428 & 1374 & 6.155 & 0.419 \\
\hline Mother’s father's age & 1564 & 76.270 & 8.668 & 1363 & 74.905 & 9.104 \\
\hline Mother's father's schooling & 1529 & 9.300 & 2.661 & 1335 & 9.317 & 2.517 \\
\hline Mother’s mother's age & 1571 & 72.535 & 7.963 & 1372 & 71.255 & 8.295 \\
\hline Mother's mother's schooling & 1560 & 8.492 & 1.846 & 1360 & 8.532 & 1.786 \\
\hline Mother's age & 1571 & 43.491 & 4.143 & 1375 & 43.461 & 4.354 \\
\hline \multicolumn{7}{|l|}{ Mother's years working: } \\
\hline At child age $6<$ age $<16$ & 1571 & 7.765 & 2.977 & 1375 & 7.877 & 2.815 \\
\hline At child age $0<$ age $<3$ & 1571 & 1.914 & 1.222 & 1375 & 1.969 & 1.210 \\
\hline At child age $3<$ age $<6$ & 1571 & 1.965 & 1.257 & 1375 & 2.043 & 1.241 \\
\hline Mother's years of schooling & 1571 & 12.845 & 2.823 & 1375 & 12.831 & 2.740 \\
\hline
\end{tabular}


Table 1D. Descriptive statistics for the adoption sample.

\begin{tabular}{|c|c|c|c|}
\hline & $\begin{array}{c}\# \\
\text { observations }\end{array}$ & Mean & $\begin{array}{l}\text { Standard } \\
\text { deviation }\end{array}$ \\
\hline Gender & 588 & 0.500 & 0.500 \\
\hline 6 month $\leq$ age $<12$ months at adoption & 588 & 0.367 & 0.482 \\
\hline Age in months at time of adoption & 588 & 5.226 & 1.984 \\
\hline Father's age & 588 & 51.849 & 3.774 \\
\hline \multicolumn{4}{|l|}{ Father's experience } \\
\hline $6<$ age $<16$ & 588 & 9.483 & 1.557 \\
\hline $0<$ age $<3$ & 588 & 2.948 & 0.299 \\
\hline $3<$ age $<6$ & 588 & 2.915 & 0.398 \\
\hline Father’s schooling & 588 & 13.614 & 3.269 \\
\hline Father's father's age & 573 & 85.086 & 8.913 \\
\hline Father's father's schooling & 522 & 9.320 & 2.979 \\
\hline Father's mother’s age & 573 & 81.501 & 8.166 \\
\hline Father's mother's schooling & 550 & 8.535 & 1.897 \\
\hline Exam in mathematics & 588 & 0.381 & 0.486 \\
\hline Exam in Norwegian, primary form & 588 & 0.218 & 0.413 \\
\hline Exam in Norwegian, secondary form & 588 & 0.214 & 0.411 \\
\hline Exam score & 588 & 3.661 & 1.005 \\
\hline Log of family income 10 years prior to exam & 588 & 6.210 & 0.470 \\
\hline Mother's father's age & 567 & 83.386 & 8.943 \\
\hline Mother's father's schooling & 513 & 9.203 & 2.739 \\
\hline Mother’s mother’s age & 578 & 80.007 & 8.539 \\
\hline Mother's mother's schooling & 547 & 8.488 & 1.806 \\
\hline Mother's age & 588 & 49.949 & 3.649 \\
\hline \multicolumn{4}{|l|}{ Mother's experience } \\
\hline $6<$ age $<16$ & 588 & 8.165 & 2.955 \\
\hline $0<$ age $<3$ & 588 & 2.287 & 1.048 \\
\hline $3<$ age $<6$ & 588 & 2.283 & 1.131 \\
\hline Mother's schooling & 588 & 12.420 & 3.859 \\
\hline
\end{tabular}


Table 2. Estimates of mothers' and fathers' education on children's school performance. OLS results of all non-adopted students.

\begin{tabular}{lcccccc}
\hline & $(1)$ & $(2)$ & $(3)$ & $(4)$ & $(12)$ & $(4)$ \\
\hline Mother's schooling & $0.098^{* *}$ & & $0.072^{* *}$ & $0.066^{* *}$ & $0.056^{* *}$ & $0.067^{* *}$ \\
& $(0.001)$ & & $(0.001)$ & $(0.001)$ & $(0.001)$ & $(0.001)$ \\
Father's schooling & & $0.103^{* *}$ & $0.071^{* *}$ & $0.064^{* *}$ & $0.053^{* *}$ & $0.063^{* *}$ \\
& & $(0.001)$ & $(0.001)$ & $(0.001)$ & $(0.001)$ & $(0.001)$ \\
Log of family income & & & & $0.146^{* *}$ & $0.140^{* *}$ & $0.154^{* *}$ \\
& & & & $(0.003)$ & $(0.004)$ & $(0.004)$ \\
Mother's mother's sch. & & & & & $0.022^{* *}$ & \\
& & & & & $0.001)$ & \\
Mother's father's sch. & & & & & $0.015^{* *}$ & \\
& & & & & $0.001)$ & \\
Father's mother's sch. & & & & & $0.022^{* *}$ & \\
& & & & & $0.001)$ & \\
Father's father's sch. & & & & & $0.010^{* *}$ & \\
& & & & & & \\
Constant & $0.909^{* *}$ & $1.259^{* *}$ & $0.541^{* *}$ & $-0.132^{* *}$ & $-0.720^{* *}$ & $-0.215^{* *}$ \\
& $(0.019)$ & $0.018)$ & $(0.019)$ & $(0.025)$ & $0.030)$ & $(0.028)$ \\
\hline Observations & 271452 & 271452 & 271452 & 271392 & 235948 & 235948 \\
$\mathrm{R}^{2}$ & 0.15 & 0.14 & 0.18 & 0.18 & 0.19 & 0.18 \\
\hline
\end{tabular}

Standard errors in brackets, ${ }^{*}$ significant at $5 \%$; ${ }^{* *}$ at $1 \%$.

Controls included: exam subject, pupil cohort, gender, age of parents/grandparents.

Table 3. Estimates of mothers' and fathers' education on children's school performance. All cousins using grandparent fixed effects.

\begin{tabular}{lcccccc}
\hline & \multicolumn{3}{c}{ Mothers are sisters } & \multicolumn{3}{c}{ Fathers are brothers } \\
\cline { 2 - 7 } & $(1)$ & $(2)$ & $(3)$ & $(4)$ & $(5)$ & $(6)$ \\
\hline Mother's schooling & $0.039^{* *}$ & $0.037^{* *}$ & $0.037^{* *}$ & $0.061^{* *}$ & $0.058^{* *}$ & $0.051^{* *}$ \\
& $(0.002)$ & $(0.002)$ & $(0.003)$ & $(0.002)$ & $(0.002)$ & $(0.003)$ \\
Father's schooling & $0.054^{* *}$ & $0.049^{* *}$ & $0.043^{* *}$ & $0.045^{* *}$ & $0.041^{* *}$ & $0.041^{* *}$ \\
& $(0.002)$ & $(0.002)$ & $(0.003)$ & $(0.003)$ & $(0.003)$ & $(0.003)$ \\
Log of family income & & $0.119^{* *}$ & $0.133^{* *}$ & & $0.126^{* *}$ & $0.121^{* *}$ \\
& & $(0.012)$ & $(0.014)$ & & $(0.013)$ & $(0.014)$ \\
Mother's mother's sch. & & & & & & $0.015^{* *}$ \\
& & & & & & $(0.004)$ \\
Mother's father's sch. & & & & & & $0.016^{* *}$ \\
& & & & & & \\
Father's mother's sch. & & & $0.024^{* *}$ & & & \\
& & & $0.004)$ & & & \\
Father's father's sch. & & & $(0.003)$ & & & \\
& & & & & & \\
Constant & $1.994^{* *}$ & $1.426^{* *}$ & $2.713^{* *}$ & $1.553^{* *}$ & $0.957^{* *}$ & $2.100^{* *}$ \\
& $(0.121)$ & $(0.134)$ & $(0.334)$ & $(0.132)$ & $(0.146)$ & $(0.344)$ \\
\hline Observations & 55870 & 55857 & 50699 & 51054 & 51044 & 47198 \\
Number of groups & 21055 & 21055 & 20417 & 19147 & 19147 & 18541 \\
$\mathrm{R}^{2}$ & 0.08 & 0.08 & 0.08 & 0.09 & 0.09 & 0.09 \\
\hline
\end{tabular}

Standard errors in brackets, * significant at 5\%; ** at $1 \%$.

Controls included: exam subject, pupil cohort, gender, age of parents/grandparents. 
Table 4. Estimates of mothers' and fathers' education on children's school performance. Cousins with twin mothers or fathers using grandparent fixed effects.

\begin{tabular}{lcccccc}
\hline & \multicolumn{3}{c}{ Mothers are twins } & \multicolumn{3}{c}{ Fathers are twins } \\
\cline { 2 - 7 } & $(1)$ & $(2)$ & $(3)$ & $(4)$ & $(5)$ & $(6)$ \\
\hline Mother's schooling & -0.012 & -0.016 & -0.004 & $0.093^{* *}$ & $0.093^{* *}$ & $0.091^{* *}$ \\
Father's schooling & $(0.018)$ & $(0.019)$ & $(0.021)$ & $(0.015)$ & $(0.015)$ & $(0.017)$ \\
& $0.061^{* *}$ & $0.054^{* *}$ & $0.034^{*}$ & 0.037 & 0.036 & 0.042 \\
Log of family income & $(0.013)$ & $(0.014)$ & $(0.015)$ & $(0.021)$ & $(0.021)$ & $(0.022)$ \\
& & $0.224^{*}$ & $0.272^{*}$ & & 0.022 & 0.022 \\
Mother's mother's sch. & & $(0.096)$ & $(0.107)$ & & $(0.113)$ & $(0.122)$ \\
& & & & & & 0.037 \\
Mother's father's sch. & & & & & & $0.027)$ \\
& & & & & & -0.013 \\
Father's mother's sch. & & & -0.002 & & & \\
& & & $(0.023)$ & & & \\
Father's father's sch. & & & 0.012 & & & \\
& & & $(0.016)$ & & & \\
Constant & & & & & & \\
& & & & & & \\
& & & & & & \\
Observations & $1.097^{* *}$ & $2.477^{*}$ & 2.987 & $2.983^{*}$ & $2.919 *$ & 1.12 \\
Number of groups & 1571 & 1571 & 1416 & 1375 & 1374 & 1254 \\
$\mathrm{R}^{2}$ & 587 & 587 & 562 & 517 & 517 & 486 \\
\hline
\end{tabular}

Standard errors in brackets, * significant at $5 \% ; * *$ at $1 \%$.

Controls included: exam subject, pupil cohort, gender, age of parents/grandparents.

Table 5. Korean-born adoptees and own birth cousins of adoptees. Estimates of mothers' and fathers' education on children's school performance.

\begin{tabular}{lcccccccc}
\hline & \multicolumn{4}{c}{ Adoptees } & \multicolumn{5}{c}{ Cousins of adoptees } \\
\cline { 2 - 9 } & $(1)$ & $(2)$ & $(3)$ & $(4)$ & $(5)$ & $(6)$ & $(7)$ & $(8)$ \\
\hline Mother's schooling & $0.031^{* *}$ & & $0.024^{*}$ & $0.022^{*}$ & $0.091^{* *}$ & & $0.060^{* *}$ & $0.059^{* *}$ \\
& $(0.010)$ & & $(0.011)$ & $(0.011)$ & $(0.012)$ & & $(0.012)$ & $(0.012)$ \\
Father's schooling & & $0.036^{* *}$ & 0.022 & 0.019 & & $0.114^{* *}$ & $0.088^{* *}$ & $0.088^{* *}$ \\
& & $(0.012)$ & $(0.013)$ & $(0.014)$ & & $(0.012)$ & $(0.013)$ & $(0.013)$ \\
Log of family & & & & & & & & 0.013 \\
income & & & & 0.081 & & & & $(0.049)$ \\
& & & & $(0.092)$ & & & & 0.566 \\
Constant & $2.831^{* *}$ & $3.808^{* *}$ & $3.209^{* *}$ & $2.748^{* *}$ & $0.984^{*}$ & $1.205^{* *}$ & 0.505 \\
& $(0.593)$ & $(0.616)$ & $(0.665)$ & $(0.848)$ & $(0.400)$ & $(0.392)$ & $(0.418)$ & $(0.481)$ \\
\hline Observations & 588 & 588 & 588 & 588 & 750 & 750 & 750 & 750 \\
$\mathrm{R}^{2}$ & 0.10 & 0.10 & 0.11 & 0.11 & 0.14 & 0.16 & 0.19 & 0.19 \\
\hline
\end{tabular}

Standard errors in brackets, * significant at $5 \%$; ** significant at $1 \%$

Controls included: exam subject, pupil cohort, gender, age of parents/grandparents and age at adoption for adoptees 
Table 6a .Estimates of mothers' and fathers' education on children's school performance. 2SLS estimates with education of partner's sibling as instrument.

\begin{tabular}{|c|c|c|c|c|}
\hline & \multicolumn{2}{|c|}{ Mothers are sisters } & \multicolumn{2}{|c|}{ Fathers are brothers } \\
\hline & (1) 2SLS & (2) 2SLS & (3) $2 \mathrm{SLS}$ & (4) $2 \mathrm{SLS}$ \\
\hline \multirow[t]{2}{*}{ Mother's schooling } & $0.146 * *$ & $0.104 * *$ & $0.090^{* *}$ & $0.060 * *$ \\
\hline & $(0.009)$ & $(0.015)$ & $(0.002)$ & $(0.003)$ \\
\hline \multirow[t]{2}{*}{ Father's schooling } & $0.092^{* *}$ & $0.060^{* *}$ & $0.141^{* *}$ & $0.075^{* *}$ \\
\hline & $(0.002)$ & $(0.003)^{* *}$ & $(0.009)$ & $(0.015)$ \\
\hline Observations & 39560 & 39560 & 36743 & 36743 \\
\hline Grandparent fixed effects & No & Yes & No & Yes \\
\hline $\mathrm{R}^{2}$ & 0.13 & 0.05 & 0.12 & 0.05 \\
\hline \# groups & & 19220 & & 17682 \\
\hline
\end{tabular}

Standard errors in brackets, not corrected for predicted variables.

* significant at $5 \%$; ** significant at $1 \%$.

Father's (mother's) schooling is not instrumented in the sample of sibling mothers (fathers). First stage regression is run for the entire sample of 187270 observations, using age of parent and schooling and age of partner's sibling(s) as regressors. $\mathrm{R}^{2}$ in the first stage regression is 0.05 , t-values on the in-laws' education range from 85-91.

Other controls included: exam subject, pupil cohort, gender, age of parents

Table 6b. Estimates of mothers' and fathers' education on children's school performance. 2SLS estimates. Twin parents with education of partner's sibling as instrument.

\begin{tabular}{lcccc}
\hline & \multicolumn{2}{c}{ Mothers are twins } & \multicolumn{2}{c}{ Fathers are twins } \\
\cline { 2 - 5 } & $(1) 2 \mathrm{SLS}$ & $(2) 2 \mathrm{SLS}$ & $(3) 2 \mathrm{SLS}$ & $(4) 2 \mathrm{SLS}$ \\
\hline Mother's schooling & 0.063 & -0.044 & $0.114^{* *}$ & $0.099^{* *}$ \\
& $(0.056)$ & $(0.086)$ & $(0.012)$ & $(0.021)$ \\
Father's schooling & $0.107^{* *}$ & $0.081^{* *}$ & 0.071 & 0.064 \\
& $(0.011)$ & $(0.019)$ & $(0.052)$ & $(0.085)$ \\
\hline Observations & & & & \\
Grandparent fixed effects & 1112 & 1112 & 1009 & 1009 \\
Groups & No & Yes & No & Yes \\
$\mathrm{R}^{2}$ & & 526 & & 485 \\
\hline
\end{tabular}

Standard errors in brackets, not corrected for predicted variables.

* significant at 5\%; ** significant at $1 \%$.

Father's (mother's) schooling is not instrumented in the sample of sibling mothers (fathers). First stage regression is run for the entire sample of 187270 observations, using age of parent and schooling and age of partner's sibling(s) as regressors. $\mathrm{R}^{2}$ in the first stage regression is 0.05 , t-values on the in-laws' education range from 85-91.

Controls included: exam subject, pupil cohort, gender, age of parents 
Table 7a. Estimates of mothers' and fathers' education on children's school performance. Non-linear effects of education of all non-adopted students.

\begin{tabular}{|c|c|c|c|c|c|c|c|}
\hline & (1) & (2) & (3) & (4) & (5) & (5) & (6) \\
\hline Mother's schooling & & & & & $\begin{array}{c}0.066 * * \\
(0.001)\end{array}$ & $\begin{array}{c}0.056^{* *} \\
(0.001)\end{array}$ & \\
\hline Father's schooling & & & & & $\begin{array}{l}0.064^{* *} \\
(0.001)\end{array}$ & $\begin{array}{l}0.053^{* *} \\
(0.001)\end{array}$ & \\
\hline Log of family income & & & & $\begin{array}{c}0.137 * * \\
(0.003)\end{array}$ & $\begin{array}{l}0.146^{* *} \\
(0.003)\end{array}$ & $\begin{aligned} 0.139 * * \\
(0.004)\end{aligned}$ & $\begin{array}{l}0.139 * * \\
(0.003)\end{array}$ \\
\hline Mother's mother's sch. & & & & & & $\begin{array}{l}0.022 * * \\
(0.001)\end{array}$ & \\
\hline Mother's father's sch. & & & & & & $\begin{array}{l}0.015^{* *} \\
(0.001)\end{array}$ & \\
\hline Father's mother's sch. & & & & & & $\begin{array}{c}0.022 * * \\
(0.001)\end{array}$ & \\
\hline Father's father's sch. & & & & & & $\begin{array}{l}0.010^{* *} \\
(0.001)\end{array}$ & \\
\hline M's sch. * F's sch. & & & & & $\begin{array}{c}0.001 * * \\
(0.000)\end{array}$ & $\begin{array}{c}-0.001^{* *} \\
(0.000)\end{array}$ & \\
\hline M’s sch *(m’s sch $\geq$ f's sch) & & & & & & & $\begin{array}{l}0.088^{* *} \\
(0.001)\end{array}$ \\
\hline $\begin{array}{l}\text { M's sch. *(m's sch. < f's } \\
\text { sch.) }\end{array}$ & & & & & & & $\begin{array}{l}0.036^{* *} \\
(0.001)\end{array}$ \\
\hline $\begin{array}{l}\text { F's sch. *(m's sch. < f's } \\
\text { sch.) }\end{array}$ & & & & & & & $\begin{array}{l}0.096 * * \\
(0.001)\end{array}$ \\
\hline F'sch *(m’s sch. $\geq$ f's sch.) & & & & & & & $\begin{array}{l}0.049 * * \\
(0.001)\end{array}$ \\
\hline F's sch. *(f's sch. < 13) & & $\begin{array}{c}0.081^{* *} \\
(0.001)\end{array}$ & $\begin{array}{c}0.053^{* *} \\
(0.001)\end{array}$ & $\begin{array}{l}0.048^{* *} \\
(0.001)\end{array}$ & & & \\
\hline F's sch. *(f's sch. $\geq 13$ ) & & $\begin{array}{c}0.089 * * \\
(0.001)\end{array}$ & $\begin{array}{c}0.061^{* *} \\
(0.001)\end{array}$ & $\begin{array}{l}0.055^{* *} \\
(0.001)\end{array}$ & & & \\
\hline M’s sch. *(m’s sch. < 13) & $\begin{array}{c}0.059 * * \\
(0.001)\end{array}$ & & $\begin{array}{l}0.038^{* *} \\
(0.001)\end{array}$ & $\begin{array}{l}0.035 * * \\
(0.001)\end{array}$ & & & \\
\hline M’s sch. *(m’s sch. $\geq 13$ ) & $\begin{array}{l}0.077^{* *} \\
(0.001)\end{array}$ & & $\begin{array}{l}0.054^{* *} \\
(0.001)\end{array}$ & $\begin{array}{l}0.050 * * \\
(0.001)\end{array}$ & & & \\
\hline Constant & $\begin{array}{l}1.319 * * \\
(0.022)\end{array}$ & $\begin{array}{l}1.193^{* *} \\
(0.021)\end{array}$ & $\begin{array}{l}1.031^{* *} \\
(0.023)\end{array}$ & $\begin{array}{c}0.368^{* *} \\
(0.028)\end{array}$ & $\begin{array}{c}-0.097^{* *} \\
(0.025) \\
\end{array}$ & $\begin{array}{c}-0.710^{* *} \\
(0.030)\end{array}$ & $\begin{array}{c}-0.112^{* *} \\
(0.025)\end{array}$ \\
\hline $\begin{array}{l}\text { Observations } \\
\mathrm{R}^{2}\end{array}$ & $\begin{array}{c}271452 \\
0.15 \\
\end{array}$ & $\begin{array}{c}271452 \\
0.15 \\
\end{array}$ & $\begin{array}{c}271452 \\
0.18 \\
\end{array}$ & $\begin{array}{c}271392 \\
0.19 \\
\end{array}$ & $\begin{array}{c}271392 \\
0.18 \\
\end{array}$ & $\begin{array}{c}235948 \\
0.19 \\
\end{array}$ & $\begin{array}{c}271392 \\
0.19 \\
\end{array}$ \\
\hline
\end{tabular}

Standard errors in brackets, * significant at $5 \%$; ** at $1 \%$.

Controls included: exam subject, pupil cohort, gender, age of parents/grandparents. 
Table 7b. Estimates of mothers' and fathers' education on children's school performance. Non-linear effects of education when mothers or fathers are twins.

\begin{tabular}{lcc}
\hline & $\begin{array}{c}\text { Mothers are } \\
\text { twins }\end{array}$ & $\begin{array}{c}\text { Fathers are } \\
\text { twins }\end{array}$ \\
\hline Mother's schooling (mother $>=$ father) & -0.042 & $0.101^{* *}$ \\
& $(0.025)$ & $(0.025)$ \\
Mother's schooling (mother $<$ father) & -0.007 & $0.086^{* *}$ \\
& $(0.029)$ & $(0.030)$ \\
Father's schooling (mother<father) & 0.041 & 0.042 \\
& $(0.027)$ & $(0.031)$ \\
Father's schooling (mother $>=$ father) & $0.081^{* *}$ & 0.027 \\
& $(0.021)$ & $(0.031)$ \\
Log of family income & $0.228^{*}$ & 0.021 \\
& $(0.096)$ & $(0.113)$ \\
Constant & $2.457^{*}$ & $2.916^{*}$ \\
& $(1.126)$ & $(1.354)$ \\
\hline Observations & 1571 & 1374 \\
Grandparent fixed effects & Yes & Yes \\
Groups & 587 & 517 \\
$\mathrm{R}^{2}$ & 0.10 & 0.11 \\
\hline
\end{tabular}

Standard errors in brackets, * significant at $5 \%$; ** at $1 \%$.

Controls included: exam subject, pupil cohort, gender, age of parents/grandparents.

\section{Table 8. Descriptive statistics of mother's experience by their education and} children's age.

\begin{tabular}{lccccccc}
\hline & \multicolumn{3}{c}{ Mothers' experience by child age } & \multicolumn{2}{c}{ Fathers' experience by child age } \\
\cline { 2 - 8 } Father's sch & \# obs & $0<$ years $<3$ & $3<$ years $<6$ & $6<$ years $<16$ & $0<$ years $<3$ & $3<$ years $<6$ & $6<$ years $<16$ \\
\hline Mandatory & 57227 & 1.69 & 1.76 & 7.23 & 2.69 & 2.66 & 8.62 \\
3 & 39488 & 1.83 & 1.94 & 7.70 & 2.81 & 2.77 & 9.02 \\
4 & 86738 & 1.88 & 1.95 & 7.67 & 2.88 & 2.88 & 9.43 \\
5 & 14230 & 1.94 & 2.02 & 7.82 & 2.81 & 2.80 & 9.26 \\
Some college & 49692 & 2.17 & 2.24 & 8.23 & 2.87 & 2.88 & 9.49 \\
College & 21729 & 2.18 & 2.28 & 8.34 & 2.86 & 2.92 & 9.63 \\
Master + & 2348 & 2.29 & 2.41 & 8.58 & 2.87 & 2.96 & 9.69 \\
\hline
\end{tabular}

\begin{tabular}{lccccccc}
\hline & \multicolumn{4}{c}{ Mothers' experience by child age } & \multicolumn{2}{c}{ Fathers' experience by child age } \\
\cline { 2 - 7 } Mothers' sch & \# obs & $0<$ years $<3$ & 3<years $<6$ & $6<$ years $<16$ & $0<$ years $<3$ & $3<$ years $<6$ & $6<$ years $<16$ \\
\hline Mandatory & 71683 & 1.44 & 1.51 & 6.59 & 2.76 & 2.75 & 8.99 \\
3 & 44170 & 1.80 & 1.91 & 7.63 & 2.84 & 2.81 & 9.22 \\
4 & 64307 & 2.00 & 2.07 & 7.98 & 2.83 & 2.83 & 9.25 \\
5 & 7917 & 2.03 & 2.02 & 7.94 & 2.84 & 2.83 & 9.31 \\
Some college & 73978 & 2.29 & 2.38 & 8.57 & 2.85 & 2.86 & 9.37 \\
College & 8670 & 2.40 & 2.55 & 8.93 & 2.82 & 2.87 & 9.47 \\
Master + & 727 & 2.64 & 2.81 & 9.59 & 2.85 & 2.91 & 9.51 \\
\hline
\end{tabular}


Table 9a. Estimates of mothers' and fathers' work experience on children's school performance. OLS results of all non-adopted students.

\begin{tabular}{lcccc}
\hline & $(1)$ & $(2)$ & $(3)$ & $(4)$ \\
\hline Mother's schooling & $0.092^{* *}$ & & $0.066^{* *}$ & $0.063^{* *}$ \\
Mother's exp when child $0<$ years $<3$ & $(0.001)$ & & $(0.001)$ & $(0.001)$ \\
& $0.023^{* *}$ & & $0.022^{* *}$ & $0.022^{* *}$ \\
Mother'sexp when child 3<years<6 & $(0.003)$ & & $(0.003)$ & $(0.003)$ \\
& $0.011^{* *}$ & & $0.008^{* *}$ & $0.009^{* *}$ \\
Mother's exp when child 6<years<16 & $(0.002)$ & & $(0.002)$ & $(0.002)$ \\
& $0.004^{* *}$ & & $0.003^{* *}$ & $-0.004^{* *}$ \\
Father's schooling & $(0.001)$ & & $(0.001)$ & $(0.001)$ \\
& & & $0.068^{* *}$ & $0.064^{* *}$ \\
Father's exp when child $0<$ years<3 & & $0.099^{* *}$ & $(0.001)$ & $(0.001)$ \\
Father's exp when child 3<years<6 & & $(0.001)$ & $0.028^{* *}$ & $0.024^{* *}$ \\
Father's exp when child 6<years<16 & & $0.036^{* *}$ & $(0.004)$ & $(0.004)$ \\
Log family income & & $(0.005)$ & $0.019^{* *}$ & $0.014^{* *}$ \\
Constant & & $0.023^{* *}$ & $(0.004)$ & $(0.004)$ \\
\hline Rbservations & & $(0.004)$ & $0.019^{* *}$ & 0.001 \\
\hline Standard & & $0.024^{* *}$ & $(0.001)$ & $(0.001)$ \\
& & $(0.001)$ & & $0.121^{* *}$
\end{tabular}

Standard errors in brackets, * significant at $5 \%$; ** at $1 \%$.

Controls included: exam subject, pupil cohort, gender, age of parents/grandparents.

Table 9b. Estimates of mothers' work experience on children's school performance. Cousins with twin mothers or fathers using grandparent fixed effects.

Mothers schooling Mothers are twins Fathers are twins

Fathers schooling

$(0.019) \quad(0.016)$

$0.054 * * \quad 0.034$

Log family income

(0.014) (0.021)

$0.241 \quad-0.017$

Mother's exp when child $0<$ years $<3$

(0.126)

$(0.158)$

0.053

$0.101^{*}$

$(0.041)$

(0.048)

Mother's exp when child $3<$ years $<6$

$$
0
$$

(0.038)

0.01

Mother’s exp when child $6<$ years $<16$

$$
0
$$

$$
\text { Mother's exp when child } 6<\text { years }<16
$$

Observations

(0.015)

Grandparent fixed effects

Groups

1571

Yes

587

0.015

(0.018)

$\mathrm{R}^{2}$ 


\section{Appendix}

Table A1

Estimates of mothers' and fathers' education on children's school performance. All cousins using OLS.

\begin{tabular}{lcccccc}
\hline & $(1)$ & $(2)$ & $(3)$ & $(4)$ & $(5)$ & $(6)$ \\
\hline Mother's schooling & $0.070^{* *}$ & $0.065^{* *}$ & $0.055^{* *}$ & $0.074^{* *}$ & $0.069^{* *}$ & $0.057^{* *}$ \\
& {$[0.002]$} & {$[0.002]$} & {$[0.002]$} & {$[0.002]$} & {$[0.002]$} & {$[0.002]$} \\
Father's schooling & $0.073^{* *}$ & $0.066^{* *}$ & $0.054^{* *}$ & $0.069^{* *}$ & $0.061^{* *}$ & $0.051^{* *}$ \\
& {$[0.002]$} & {$[0.002]$} & {$[0.002]$} & {$[0.002]$} & {$[0.002]$} & {$[0.002]$} \\
Log family income & & $0.159^{* *}$ & $0.152^{* *}$ & & $0.158^{* *}$ & $0.145^{* *}$ \\
& & {$[0.009]$} & {$[0.009]$} & & {$[0.009]$} & {$[0.009]$} \\
Mother's mother's sch. & & & $0.024^{* *}$ & & & $0.022^{* *}$ \\
& & & {$[0.003]$} & & & {$[0.003]$} \\
Mother's father's sch. & & & $0.015^{* *}$ & & & $0.014^{* *}$ \\
& & & {$[0.002]$} & & & {$[0.002]$} \\
Father's mother's sch. & & & $0.023^{* *}$ & & & $0.022^{* *}$ \\
& & & {$[0.003]$} & & & {$[0.003]$} \\
Father's father's sch. & & & $0.008^{* *}$ & & & $0.010^{* *}$ \\
& & & {$[0.002]$} & & & {$[0.002]$} \\
Constant & $0.311^{* *}$ & $-0.405^{* *}$ & $-0.974^{* *}$ & $0.391^{* *}$ & $-0.319^{* *}$ & $-0.810^{* *}$ \\
& {$[0.047]$} & {$[0.060]$} & {$[0.069]$} & {$[0.050]$} & {$[0.064]$} & {$[0.072]$} \\
\hline Observations & 55870 & 55857 & 50699 & 51054 & 51044 & 47198 \\
$\mathrm{R}^{2}$ & 0.18 & 0.18 & 0.19 & 0.18 & 0.18 & 0.19 \\
$\mathrm{R}^{2}$-adj & 0.18 & 0.18 & 0.19 & 0.18 & 0.18 & 0.19 \\
\hline S & & & & & & \\
\hline
\end{tabular}

Standard errors in brackets

* significant at $5 \%$; ** significant at $1 \%$

Controls: exam subject, pupil cohort, gender, age of parents/grandparents included 
Table A2

Estimates of mothers' and fathers' education on children's school performance. Cousins with twin mothers or fathers using OLS.

\begin{tabular}{lcccccc}
\hline & $(1)$ & $(2)$ & $(3)$ & $(4)$ & $(5)$ & $(6)$ \\
\hline Mother's schooling & $0.062^{* *}$ & $0.052^{* *}$ & $0.049^{* *}$ & $0.092^{* *}$ & $0.083^{* *}$ & $0.073^{* *}$ \\
& {$[0.010]$} & {$[0.010]$} & {$[0.011]$} & {$[0.011]$} & {$[0.011]$} & {$[0.012]$} \\
Father's schooling & $0.083^{* *}$ & $0.069^{* *}$ & $0.051^{* *}$ & $0.066^{* *}$ & $0.055^{* *}$ & $0.043^{* *}$ \\
& {$[0.010]$} & {$[0.010]$} & {$[0.011]$} & {$[0.011]$} & {$[0.011]$} & {$[0.013]$} \\
Log family income & & $0.307^{* *}$ & $0.281^{* *}$ & & $0.269^{* *}$ & $0.286^{* *}$ \\
& & {$[0.068]$} & {$[0.073]$} & & {$[0.072]$} & {$[0.075]$} \\
Mother's mother's sch. & & & $0.042^{*}$ & & & 0.024 \\
& & & {$[0.017]$} & & & {$[0.018]$} \\
Mother's father's sch. & & & -0.003 & & & 0.004 \\
& & & {$[0.012]$} & & & $0.013]$ \\
Father's mother's sch. & & & 0.017 & & & 0.03 \\
& & & {$[0.017]$} & & & $0.018]$ \\
Father's father's sch. & & & 0.011 & & & {$[0.012]$} \\
& & & & & \\
Constant & -0.145 & $-1.540^{* *}$ & $-1.933^{* *}$ & 0.612 & -0.603 & $-1.266^{*}$ \\
& {$[0.284]$} & {$[0.419]$} & {$[0.467]$} & {$[0.313]$} & {$[0.450]$} & {$[0.503]$} \\
\hline \# Obs & 1571 & 1571 & 1416 & 1375 & 1374 & 1254 \\
R-squared & 0.18 & 0.19 & 0.19 & 0.18 & 0.19 & 0.2 \\
R-squared adj & 0.17 & 0.18 & 0.17 & 0.18 & 0.18 & 0.19 \\
\hline S & & & & & & \\
\hline
\end{tabular}

Standard errors in brackets

* significant at $5 \%$; ** significant at $1 \%$

Controls: exam subject, pupil cohort, gender, age of parents/grandparents included 